\title{
Cytoprotective role of the aqueous extract of Terminalia chebula on renal epithelial cells
}

\author{
S. Tayal, S. Duggal, P. Bandyopadhyay, A. Aggarwal, S. Tandon, C. Tandon \\ Department of Biotechnology and Bioinformatics, Jaypee University of Information Technology, \\ Waknaghat, Solan, H.P, India
}

\section{ABSTRACT}

Purpose: Kidney stone is one of the most prevalent diseases worldwide. Calcium oxalate $(\mathrm{CaOx})$ has been shown to be the main component of the majority of stones formed in the urinary system of the patients with urolithiasis. The present study evaluates the antilithiatic properties of Terminalia chebula commonly called as "harad" which is often used in ayurveda to treat various urinary diseases including kidney stones.

Materials and Methods: The antilithiatic activity of Terminalia chebula was investigated on nucleation and growth of the calcium oxalate crystals. The protective potency of the plant extract was also tested on oxalate induced cell injury of both NRK-52E and MDCK renal epithelial cells.

Results: The percentage inhibition of $\mathrm{CaOx}$ nucleation was found $95.84 \%$ at $25 \mu \mathrm{g} / \mathrm{mL}$ of Terminalia chebula aqueous extract which remained almost constant with the increasing concentration of the plant extract; however, plant extract inhibited $\mathrm{CaOx}$ crystal growth in a dose dependent pattern. When MDCK and NRK-52E cells were injured by exposure to oxalate for 48 hours, the aqueous extract prevented the injury in a dose-dependent manner. On treatment with the different concentrations of the plant extract, the cell viability increased and lactate dehydrogenase release decreased in a concentration dependent manner.

Conclusion: Our study indicates that Terminalia chebula is a potential candidate for phytotherapy against urolithiasis as it not only has a potential to inhibit nucleation and the growth of the $\mathrm{CaOx}$ crystals but also has a cytoprotective role.

\section{ARTICLE INFO}

\section{Key words:}

urolithiasis; kidney;

phytotherapy; calculi

Int Braz J Urol. 2012; 38: 204-14

Submitted for publication:

April 29, 2011

Accepted after revision:

August 26, 2011

\section{INTRODUCTION}

Urolithiasis is a very painful disease that has afflicted a wide sector of human population since ancient times (1). Calcium-containing stones are the most common comprising about $75 \%$ of all urinary calculi, which may be in the form of pure calcium oxalate $(50 \%)$ or calcium phosphate (5\%) and a mixture of both (45\%). Cal- cium oxalate stones are found in two different varieties, calcium oxalate monohydrate (COM) or Whewellite, and calcium oxalate dihydrate (COD) or Weddellite. COM, the thermodynamically most stable form, is observed more frequently in clinical stones than COD and has a greater affinity for renal tubular cells, thus responsible for the formation of stones in the kidney (2). Crystal growth and agglomeration may be due to supersaturation with respect to stone forming constituents or the 
presence of various inhibitory or stimulatory biomolecules or even $\mathrm{pH}(3)$.

Renal tubular fluid is supersaturated with calcium and oxalate ions, which can nucleate to form crystals of calcium oxalate monohydrate. Microcrystals of COM, the most common crystal in renal stones, irreversibly bind to cell surface microvilli, are subsequently internalized and can stimulate proliferation (4). Therefore, this indicates that renal epithelial cells can bind and internalize calcium oxalate crystals.

Extracorporeal shock wave lithotripsy (ESWL) is currently the first line treatment for upper urinary tract calculi. This treatment is not without side effects and kidney damage during ESWL is a clinically significant problem (5). Therefore, it is worthwhile to look for an alternative cure and phytotherapy is proving to be a promising alternative.

Since civilization, medicinal plants are part of human society to combat diseases. Traditional knowledge of healers and venders are in great demand in the developed as well as developing countries for primary healthcare because of their wide biological and medicinal activities, higher safety margins and lesser cost (6).

Terminalia chebula locally named as "harad" in India has been extensively used in ayurveda. It is used to treat urolithiasis and is actively used in various drug formulations of kidney stone treatments like neeri (product information by AIMIL PHARMACEUTICALS (INDIA) LTD.). It is extensively explored for antimicrobial (7), antioxidant (8), anticarcinogenic (9), hypocholesterolemic (10) and diuretic $(11,12)$ activities by various research groups.

The present study is aimed to investigate the efficacy of Terminalia chebula on nucleation and growth of calcium oxalate in vitro and further examining the potency of the same on oxalate induced injury in MDCK and NRK 52E cells.

\section{MATERIALS AND METHODS}

\section{Plant material}

The fruits of Terminalia chebula used in this study were collected from Shimla, India which were identified and then authenticated by microscopical and physiochemical data.

\section{Preparation of plant extracts}

The air-dried fine powdered plant fruits were infused in distilled water until complete exhaustion. The extract was then filtered using Whatman No. 1 filter paper and the filtrate was evaporated in vacuo and dried using a rotary evaporator at $40^{\circ} \mathrm{C}$. The final dried samples were stored in labeled sterile bottles and kept at $-20^{\circ} \mathrm{C}$ and were referred to as aqueous extract (13). The various concentrations of the plant extract tested for their inhibitory potency were $25 \mu \mathrm{g} / \mathrm{mL}, 50$ $\mu \mathrm{g} / \mathrm{mL}, 100 \mu \mathrm{g} / \mathrm{mL}, 200 \mu \mathrm{g} / \mathrm{mL}, 400 \mu \mathrm{g} / \mathrm{mL}$ and $1000 \mu \mathrm{g} / \mathrm{mL}$, which were prepared at the time of experiment.

For cell culture studies a stock solution of the crude extract prepared as defined above was dissolved in dimethyl sulfoxide (DMSO) (final concentration of the DMSO in the highest concentration of plant extract tested did not exceed $0.4 \%(\mathrm{v} / \mathrm{v})$ and did not affect the cell proliferation). Further dilutions of the stock were done using serum free DMEM (Dulbecco's Modified Eagle's Media) and filtered by $0.3 \mathrm{~mm}$ syringe filter (14).

Nucleation Assay of calcium oxalate

The method used was similar to that described by Hennequin et al. with some minor modifications (15). Solutions of calcium chloride and sodium oxalate were prepared at the final concentration of $3 \mathrm{mmol} / \mathrm{L}$ and $0.5 \mathrm{mmol} / \mathrm{L}$, respectively, in a buffer containing Tris- $\mathrm{HCl} 0.05 \mathrm{~mol} / \mathrm{L}$ and $\mathrm{NaCl} 0.15 \mathrm{~mol} / \mathrm{L}$ at $\mathrm{pH} 6.5 .3 \mathrm{~mL}$ of calcium chloride. The solution was mixed with test sample at different concentrations of $25 \mu \mathrm{g} / \mathrm{mL}, 50 \mu \mathrm{g} /$ $\mathrm{mL}, 100 \mu \mathrm{g} / \mathrm{mL}, 200 \mu \mathrm{g} / \mathrm{mL}, 400 \mu \mathrm{g} / \mathrm{mL}$ and 1000 $\mu \mathrm{g} / \mathrm{mL}$. Crystallization was started by adding 1.5 $\mathrm{mL}$ of sodium oxalate solution in $1.5 \mathrm{~mL}$ calcium chloride. The temperature was maintained at $37^{\circ}$ C. The absorbance of the solution was monitored at $620 \mathrm{~nm}$ every $1 \mathrm{~min}$. The percentage inhibition produced by the aqueous extract was calculated as $\left(1-\left(T_{\mathrm{si}} / \mathrm{T}_{\mathrm{sc}}\right)\right) \mathrm{X} 100$, where $\mathrm{T}_{\mathrm{sc}}$ was the turbidity slope of the control and $\mathrm{T}_{\mathrm{si}}$ the turbidity slope in the presence of the inhibitor. 
Growth Assay of calcium oxalate

Inhibitory activity against $\mathrm{CaOx}$ crystal growth was measured using the seeded solutiondepletion assay, described previously by Nakagawa et al (16). Briefly, an aqueous solution of $10 \mathrm{mM}$ Tris- $\mathrm{HCl}$ containing $90 \mathrm{mM} \mathrm{NaCl}$ was adjusted to $\mathrm{pH}$ 7.2. Stone slurry $(1.5 \mathrm{mg} / \mathrm{mL})$ was prepared in 50mM sodium acetate buffer (pH 5.7). CaOx monohydrate crystal seed was added to a solution containing $4 \mathrm{mM}$ calcium chloride $\left(\mathrm{CaCl}_{2}\right)$ and $4 \mathrm{mM}$ sodium oxalate $\left(\mathrm{Na}_{2} \mathrm{C}_{2} \mathrm{O}_{4}\right)$. The reaction of $\mathrm{CaCl}_{2}$ and $\mathrm{Na}_{2} \mathrm{C}_{2} \mathrm{O}_{4}$ with crystal seed led to deposition of $\mathrm{CaOx}$ on the crystal surfaces, thereby decreasing free oxalate that is detectable by spectrophotometry at $\lambda 214 \mathrm{~nm}$. When various extracts at different concentrations of $25 \mu \mathrm{g} / \mathrm{mL}, 50 \mu \mathrm{g} /$ $\mathrm{mL}, 100 \mu \mathrm{g} / \mathrm{mL}, 200 \mu \mathrm{g} / \mathrm{mL}, 400 \mu \mathrm{g} / \mathrm{mL}$ and 1000 $\mu \mathrm{g} / \mathrm{mL}$ is added into this solution, depletion of free oxalate ions will decrease if the test sample inhibits $\mathrm{CaOx}$ crystal growth. Rate of reduction of free oxalate was calculated using the baseline value and the value after every $1 \mathrm{~min}$. for 20 mins. incubation with or without test sample. The relative inhibitory activity was calculated as follows: \% Relative inhibitory activity $=((\mathrm{C}-\mathrm{S}) / \mathrm{C})$ $\times 100$, where $C$ is the rate of reduction of free oxalate without any test sample and $S$ is the rate of reduction of free oxalate with a test sample.

\section{Cell Culture}

MDCK and NRK 52E cells were obtained from National Centre of Cell Sciences (NCCS, Pune, India). The cells were maintained as monolayer in DMEM with $2.0 \mathrm{mM} \mathrm{L}$-glutamine adjusted to contain $3.7 \mathrm{~g} / \mathrm{l}$ sodium bicarbonate and 4.5 $\mathrm{g} / \mathrm{l}$ glucose. Medium was supplemented with $1 \%$ penicillin (100 units/mL), streptomycin $(10,000$ $\mu \mathrm{g} / \mathrm{mL}$ ) and $10 \%$ fetal bovine serum. Cells were cultured in $25 \mathrm{~cm}^{2}$ tissue-culture treated flasks at $37^{\circ} \mathrm{C}$ and $5 \% \mathrm{CO}_{2}$ in humidified chambers.

\section{Oxalate-induced Cell Injury}

MDCK and NRK 52E cells were incubated in DMEM containing $1 \mathrm{mM}$ sodium oxalate in the presence of different concentrations of the aqueous extract of the test sample $(10,25,50$ and 80 $\mu \mathrm{g} / \mathrm{mL}$ ) for 48 hours $(14,17)$. Cell injury was assessed by measuring the cell viability through trypan blue and monitoring the lactate dehydrogenase (LDH) leakage into the medium.

\section{Cytotoxicity Trypan blue assay}

The cytotoxicity of the crude extract of T. chebula was assessed by determining the cell viability using trypan blue exclusion method. For the determination of cell viability, cells were plated at a density of $4 \times 10^{4}$ cells/well and cultured for 48 hours. The medium was replaced with serum-free medium and the cells were treated with various concentrations of the plant extracts (10, 25,50 and $80 \mu \mathrm{g} / \mathrm{mL}$ ) for a further 48 hours. The percentage viability for the cells was calculated as (live cells/total cells)* 100 .

\section{Lactate dehydrogenase leakage assay}

LDH leakage assay was performed by the method of Wagner et al. (18). Briefly, $6.6 \mathrm{mM}$ NADH and $30 \mathrm{mM}$ sodium pyruvate were prepared in Tris $(0.2 \mathrm{M}, \mathrm{pH}$ 7.3). The reaction was initiated with the addition of $50 \mu \mathrm{L}$ of the test sample and the disappearance of NADH was monitored at $340 \mathrm{~nm}$ for $5 \mathrm{~min}$. at an interval of $1 \mathrm{~min}$. The percentage of $\mathrm{LDH}$ release was calculated by dividing the activity of LDH in the supernatant by the LDH activity measured after complete cell lysis achieved by sonication.

\section{Statistical Analysis}

Data were expressed as mean values of three independent experiments (each in triplicate) and analyzed by ANOVA ( $p<0.05$ ) to estimate the differences between values of extracts tested.

\section{RESULTS}

Inhibition of Nucleation of CaOx Crystals by Terminalia chebula Extract:

Figure-1 displays the effect of aqueous extract of Terminalia chebula on the nucleation of calcium oxalate crystals. With respect to the control (with no plant sample), the percentage inhibition shown by aqueous extract at $25 \mu \mathrm{g} / \mathrm{mL}$ was $95.8 \%$ with almost constant inhibition at 100 $\mu \mathrm{g} / \mathrm{mL}, 200 \mu \mathrm{g} / \mathrm{mL}$ and $400 \mu \mathrm{g} / \mathrm{mL}$ in the range of $91-94 \%$. 
Figure 1 - Effect of crude extract of Terminalia chebula on nucleation of CaOx. Data are mean \pm S.D. of three independent observations. ${ }^{*} p<0.05$.

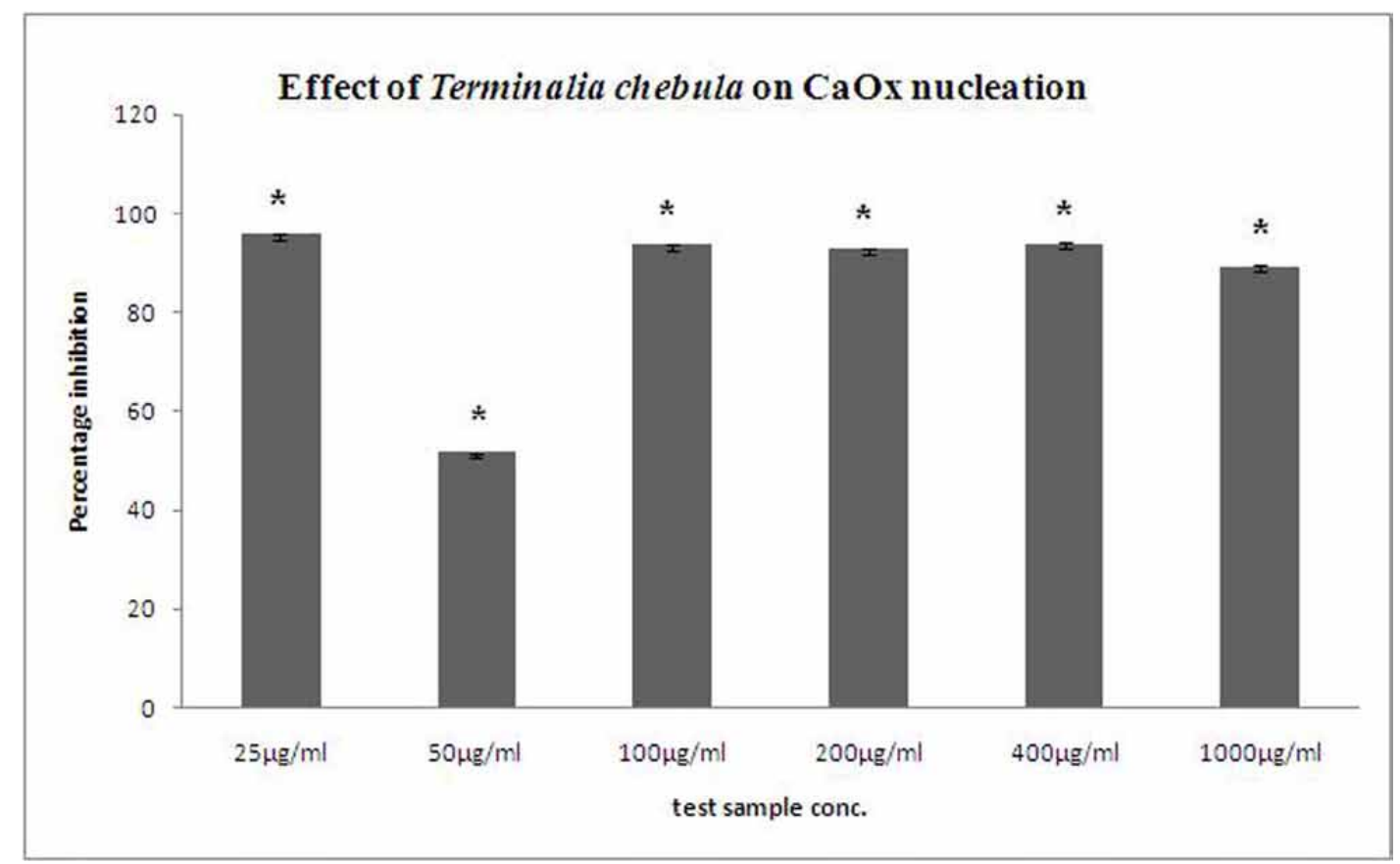

Inhibition of $\mathrm{CaOx}$ Crystal Growth by Terminalia chebula Extract:

Figure-2 displays the effect of Terminalia chebula on the growth of calcium oxalate crystals. The aqueous extract displayed concentration dependent percentage inhibition when compared to the control (with no plant extract). The percentage inhibition with $25 \mu \mathrm{g} / \mathrm{mL}$ was found to be $39.9 \%$, which increased to $105.8 \%$ with $1000 \mu \mathrm{g} /$ $\mathrm{mL}$ aqueous extract.

Diminution of Oxalate-Induced Renal Tubular Epithelial Cell Injury by Terminalia chebula Extract:

Figures- 3 and 4 depicts the protective effect of the aqueous extract of Terminalia chebula towards the renal tubular epithelial cells, MDCK and NRK-52E respectively with respect to cell viability. The oxalate induced a significant injury to the cells which could be ascertained by a decrease in viability which was greater in MDCK as compared to NRK-52E. However, the injury due to oxalate was significantly reduced in those cells treated with the T. chebula extracts. As the concentration of the extract increased from $10 \mu \mathrm{g} / \mathrm{mL}$ to $80 \mu \mathrm{g} / \mathrm{mL}$, the percentage viability improved showing that the plant has an inhibitory activity towards the oxalate which caused injury to the renal cells in a concentration dependent manner. The plant extract alone $(80 \mu \mathrm{g} / \mathrm{mL}$, containing $0.4 \%$ DMSO) had no effect on the cell injury in the absence of oxalate indicating that even at the highest concentration of DMSO used there was no cytotoxicity to the cells. The concentration dependent percentage viability was seen in both the cell lines. The viability increased from $41.3 \%$, as in oxalate injured cells to $60.4 \%$ in the presence of $80 \mu \mathrm{g} / \mathrm{mL}$ plant extract when tested with NRK52E. A similar pattern was observed with MDCK where the viability increased to $71.3 \%$ when treated with $80 \mu \mathrm{g} / \mathrm{mL}$ plant extract as compared to $52.9 \%$ viability in oxalate injured cells. 
Figure 2 - Effect of crude extract of Terminalia chebula on growth of CaOx. Data are mean \pm

S.D. of three independent observations. ${ }^{*} p<0.05$

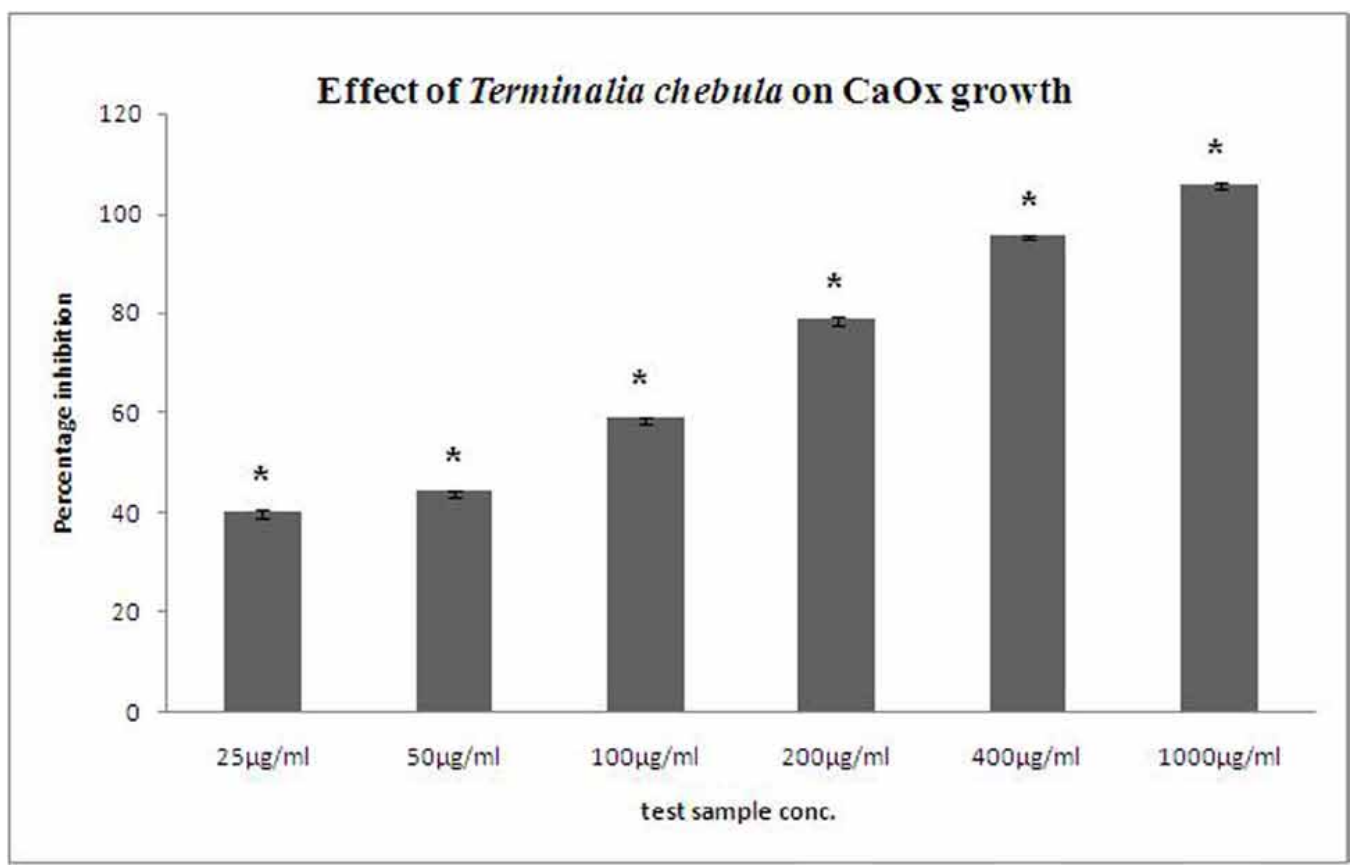

Figure 3 - Effect of Terminalia chebula on the viability of MDCK. Data are mean \pm S.D. of three independent observations. ${ }^{*} p<0.05$ versus untreated control, ${ }^{* *} p<0.05$ versus oxalate control.

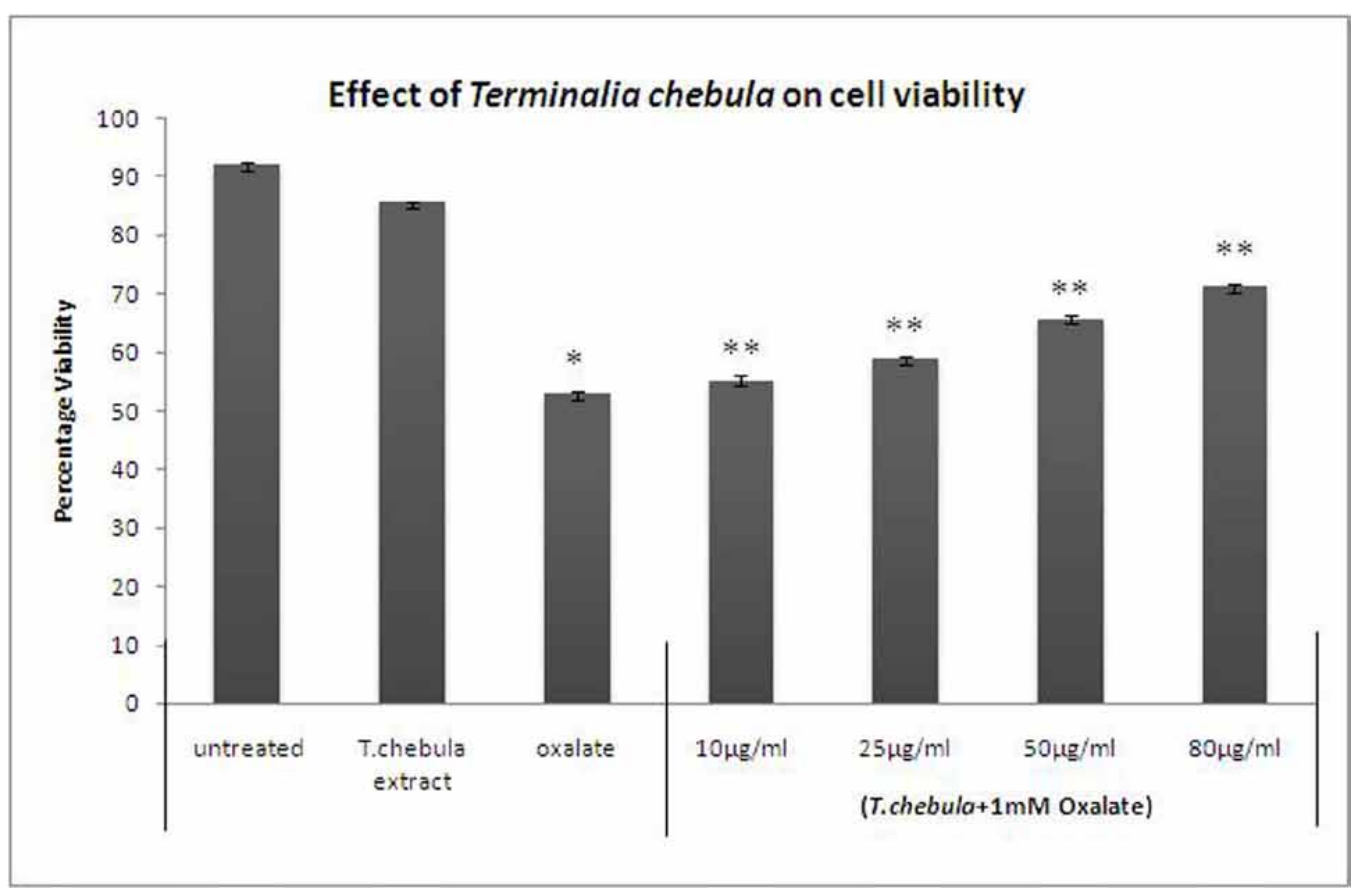


Figure 4 - Effect of Terminalia chebula on the viability of NRK-52E. Data are mean \pm S.D. of three independent observations. ${ }^{*} \mathrm{p}<0.05$ versus untreated control, ${ }^{* *} \mathrm{p}<0.05$ versus oxalate control.

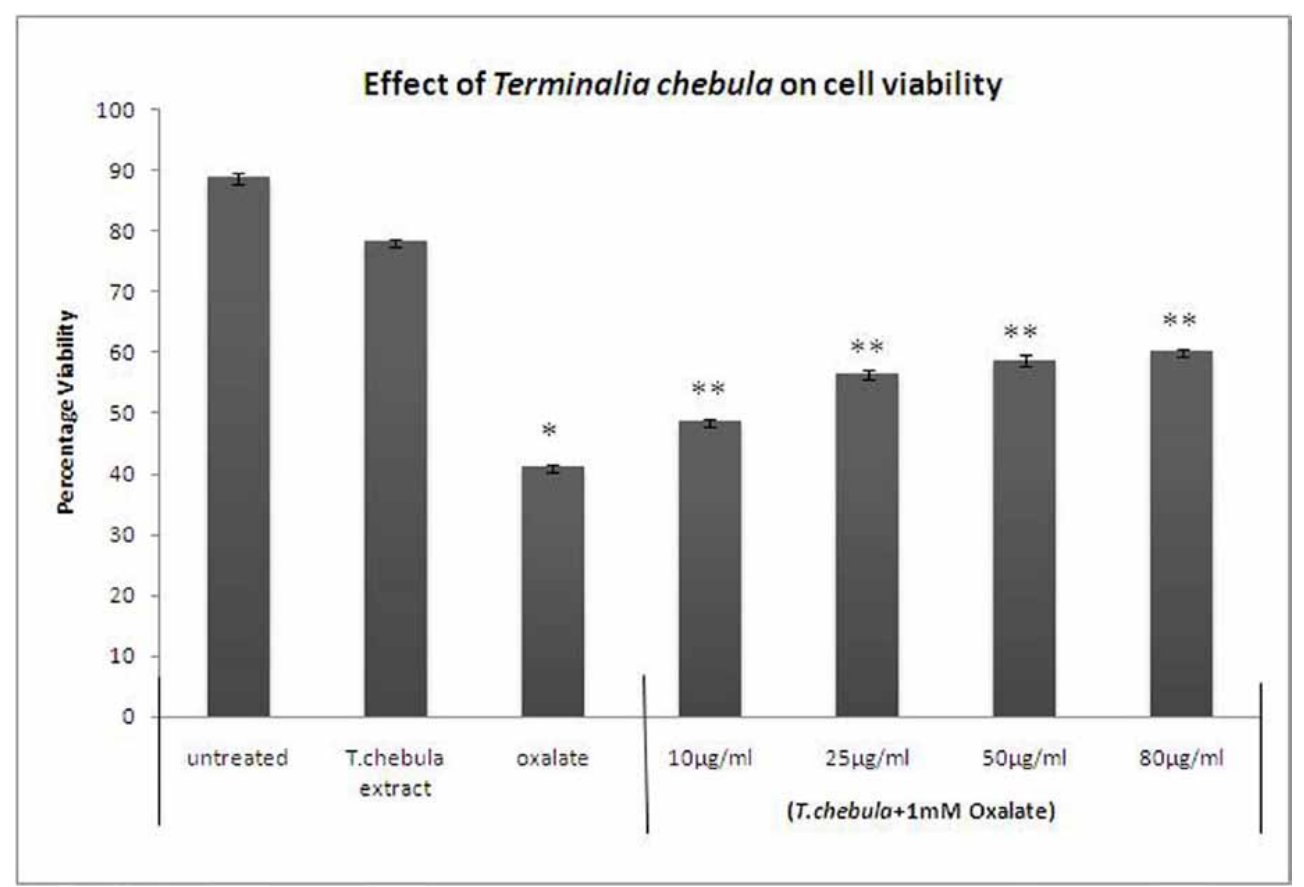

Figure 5 - Effect of Terminalia chebula on the $\%$ LDH release of MDCK. Data are mean \pm S.D. of three independent observations. ${ }^{*} p<0.05$ versus untreated control, ${ }^{* *} p<0.05$ versus oxalate control.

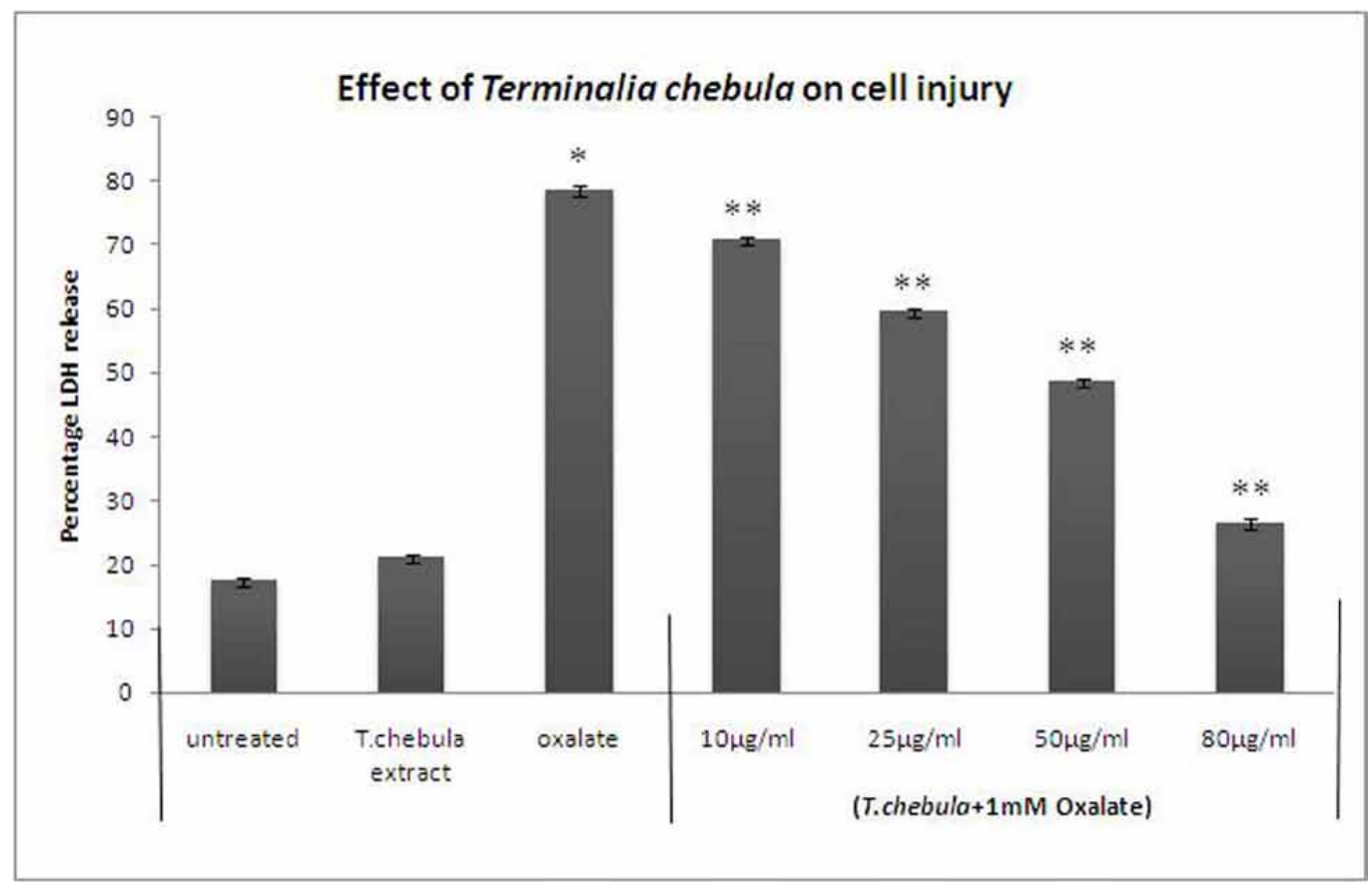


Figure 6 - Effect of Terminalia chebula on the \% LDH release of NRK-52E. Data are mean \pm S.D. of three independent observations. ${ }^{*} p<0.05$ versus untreated control, ${ }^{* *} p<0.05$ versus oxalate control.

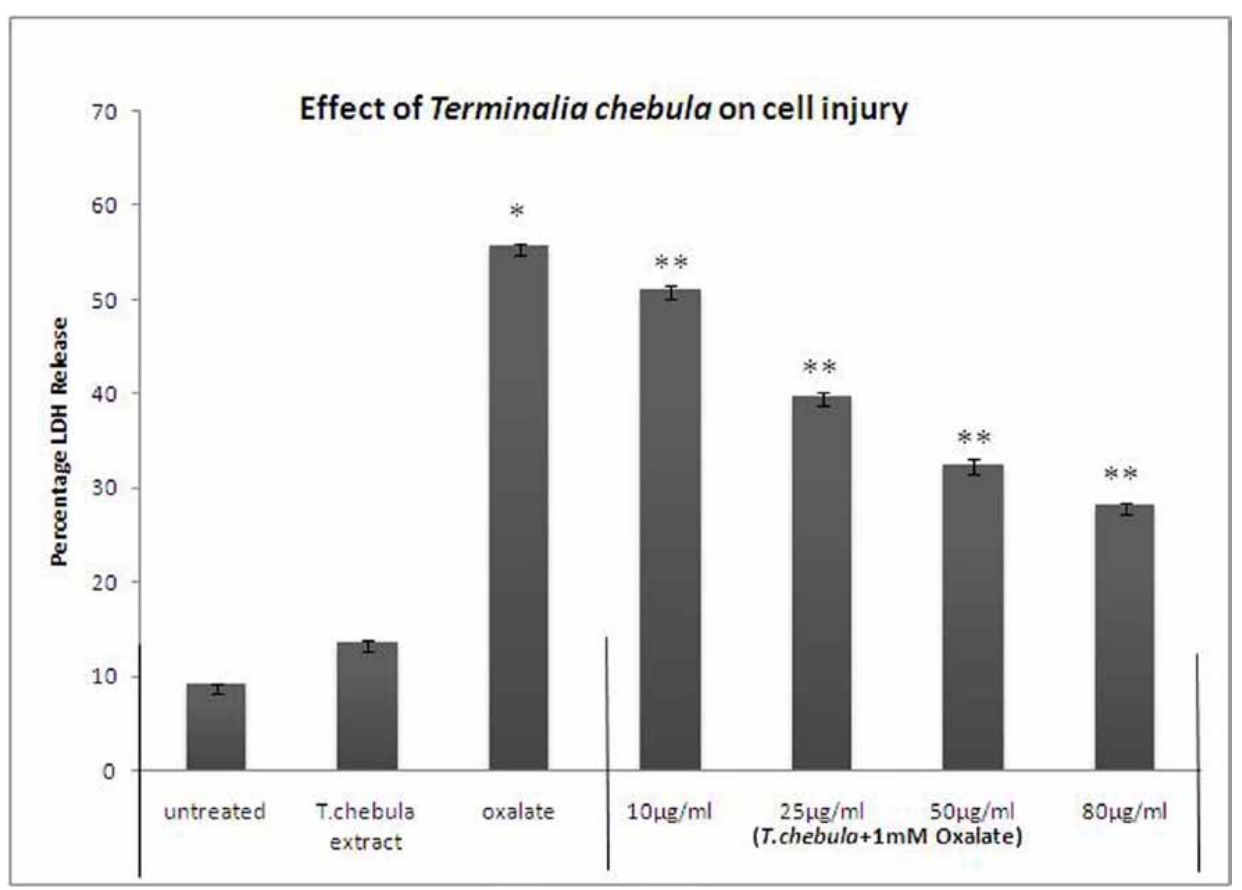

Lactate dehydrogenase is a stable cytosolic enzyme that is released when the cell is lysed or there is any injury on the cell membrane. A significant increase in LDH release was seen when both the cells were exposed to oxalate alone. When cells were treated with the plant extract at varying concentrations $(10,25,50$ and $80 \mu \mathrm{g} / \mathrm{mL})$ along with oxalate $(1 \mathrm{mM})$ for $48 \mathrm{~h}$, a reduction in oxalate-induced cell injury was observed as assessed by a decreased LDH release (Figures 5 and 6). Again it was observed that the plant extract alone had no significant effect on the measures of cell injury in the absence of oxalate. The percentage $\mathrm{LDH}$ release for MDCK and NRK-52E is dependent upon concentration after treatment with oxalate and the plant extract with respect to control. The LDH release was significantly decreased to the level of $28.2 \%$ in the treatment with 80 $\mu \mathrm{g} / \mathrm{mL}$ test sample in NRK-52E, though the LDH release with oxalate injured cells was found to be $55.8 \%$ with respect to untreated cells. MDCK cells also showed the same pattern with $78.6 \%$ LDH release in oxalate injured cells which decreased significantly to $26.7 \%$ with the highest concentration of the plant sample.

\section{DISCUSSION}

There has been a long standing quest for potent inhibitors of calcium oxalate growth as it is the most common urinary stone associated with renal injury. Recent evidence suggests that in many calcium oxalate stone formers the earliest changes may be calcium salt deposition in the medullary interstitium. In marked hyperoxaluric states, primary hyperoxaluria directs calcium oxalate crystal adhesion to renal epithelial cells (19).

Stones larger than $5 \mathrm{~mm}$ fail to pass through and hence can be treated through ESWL but the chance for stone recurrence is still about 50\%. In addition, ESWL might show some significant side effects such as renal damage, hypertension or renal impairment. Therefore, phytotherapeutic agents could be useful as either an alternative or 
a complementary therapy in the management of urolithiasis with some possible mechanisms of action including an increased excretion of urinary citrate, decreased excretion of urinary calcium and oxalate or could be attributable to diuretic, antioxidant or antibacterial effects (20).

The present investigation deals with the effects of putative litholytic medicinal plant, Terminalia chebula on CaOx crystals. Fruits of T. chebula are a popular folk medicine and have been studied for its diuretic activity but the scientific basis of its activity was not yet established. In this study, the inhibitory potency of the plant was tested on nucleation and growth of calcium oxalate crystallization in vitro. The aqueous extract inhibited the CaOx growth to the tune of $105.8 \%$. Further, a protective effect on renal epithelial cells was shown by the aqueous plant extract in a concentration-dependent manner. When MDCK and NRK-52E cells were injured by exposure to $1 \mathrm{mM}$ oxalate for $48 \mathrm{~h}$, the plant extract prevented the injury in a dose-dependent manner. The oxalate injury to MDCK cells were more intense as compared to that of NRK-52E. The percentage LDH release in NRK-52E was less at $80 \mu \mathrm{g} / \mathrm{mL}$ than MDCK. Therefore, T. chebula seems to be more responsive towards NRK-52E than MDCK.

Several traditional Chinese medicines/ plants that are used in Kampou medicine also have demonstrated their abilities to inhibit calcium oxalate crystallization. Dietary factors appear to affect the ability of urine to inhibit COM crystallization. In this regard, lemon juice has been found to inhibit the rate of crystal nucleation and aggregation (20).

Various plants are being evaluated for their antiurolithiatic potency through their activity on renal epithelial cell lines which are accepted as a powerful tool to establish the mechanism of nephrolithiasis. Atmani et al. used MDCK cell lines as a model to study the adhesion of radioactive COM crystals in the presence and absence of aqueous extract of Herniaria hirsuta and found that the crystal attachment was inhibited in a concentration dependent manner (19). In vitro effect of an aqueous extract of Phyllanthus niruri L., a plant used in Brazilian folk medicine for the treatment of urolithiasis, on a model of COM crystal endocytosis by MDCK cells, was investigated by Campos and Schor. The extract exhibited a potent and effective non-concentration-dependent inhibitory effect on the COM crystal internalization. This response was present even at very high (pathologic) COM concentrations and no Phyllanthus niruri L. induced toxic effect could be detected (21). The fruits of Ammi visnaga L. commonly called as Khella have traditionally been used in Egypt to relieve pain of kidney stone passage by drinking a tea prepared from the crushed or powdered fruits of khella. A study was undertaken to evaluate its effect on renal epithelial injury using LLC-PK1 and Madin-Darby-canine kidney (MDCK) cells. Over the past few decades two continuous renal epithelial cell lines have been most used or studying nephrolithiasis, the Madin-Darby canine kidney collecting duct tubular epithelial cells (MDCK) and porcine kidney proximal tubular epithelial cells (LLC-PK1). MDCK cells have been widely used as a model system for the distal/collecting duct and LLC-PK1 cells have retained many characteristics of the proximal tubule. Vanachayangkul et al. evaluated the effect of aqueous khella extract on oxalate induced renal injury and found that the cell injury (LDH release) was significantly reduced in cells treated with the extract (22).

The antilithiasic potency of various plants like Dolichos biflorus (23), Trachyspermum ammi (24), Tribulus terrestris (2) and Achyranthes aspera (25) and the inhibitory effect of various biomolecules on renal stones (26) have been evaluated in our lab.

The inhibitory role of various plant species from west and south of Algeria in calcium oxalate growth was investigated in vitro by Beghalia et al. (27). They further postulated that the plant extracts may contain substances that inhibit COM crystal aggregation and also the binding of the crystals to the renal epithelial surface. This could explain a decrease in LDH release observed in the cells treated with the plant extract compared to those treated with oxalate alone. The cDNA macroarray was used to evaluate gene expression in urolithiasis by exposing the COM crystals to NRK52E cells (28). 


\section{CONCLUSIONS}

This study demonstrated that Terminalia chebula extract showed cytoprotective properties towards the MDCK and NRK-52E cells by reducing the LDH leakage and increasing the cell viability. At the same time, it also has an ability to inhibit the calcium oxalate crystals in vitro. In the light of these studies, it is a valuable candidate for further pharmacological analysis.

\section{ABBREVIATIONS}

COM: calcium oxalate monohydrate

COD: calcium oxalate dihydrate

CaOx: calcium oxalate

ESWL: extra corporeal shock wave lithotripsy

MDCK: madin darby canine kidney

NRK-52E: normal rat kidney epithelial

DMSO: dimethyl sulfoxide

DMEM: dulbecco's modified eagle's media

LDH: lactate dehydrogenase

\section{CONFLICT OF INTEREST}

None declared.

\section{REFERENCES}

1. Grases F, Costa-Bauzá A, García-Ferragut L: Biopathological crystallization: a general view about the mechanisms of renal stone formation. Adv Colloid Interface Sci. 1998; 74: 169-94.

2. Aggarwal A, Tandon S, Singla SK, Tandon C: Diminution of oxalate induced renal tubular epithelial cell injury and inhibition of calcium oxalate crystallization in vitro by aqueous extract of Tribulus terrestris. Int Braz J Urol. 2010; 36: 480-8; discussion 488, 489.

3. Fan J, Schwille PO, Schmiedl A, Gottlieb D, Manoharan M, Herrmann U: Calcium oxalate crystallization in undiluted urine of healthy males: in vitro and in vivo effects of various citrate compounds. Scanning Microsc. 1999; 13: 307-19.

4. Tombolini P, Ruoppolo M, Bellorofonte C, Zaatar C, Follini M: Lithotripsy in the treatment of urinary lithiasis. J Nephrol. 2000; 13 (Suppl 3): S71-82.

5. Li X, He D, Zhang L, Xue Y, Cheng X, Luo Y: Pyrrolidine dithiocarbamate attenuate shock wave induced MDCK cells injury via inhibiting nuclear factor-kappa $B$ activation. Urol Res. 2007; 35: 193-9.
6. Kandil O, Radwan NM, Hassan AB, Amer AM, el-Banna HA, Amer WM: Extracts and fractions of Thymus capitatus exhibit antimicrobial activities. J Ethnopharmacol. 1994; 44: 19-24.

7. Lieske JC, Swift H, Martin T, Patterson B, Toback FG: Renal epithelial cells rapidly bind and internalize calcium oxalate monohydrate crystals. Proc Natl Acad Sci U S A. 1994; 91 : 6987-91.

8. Cheng HY, Lin TC, Yu KH, Yang CM, Lin CC: Antioxidant and free radical scavenging activities of Terminalia chebula. Biol Pharm Bull. 2003; 26: 1331-5.

9. Saleem A, Husheem M, Härkönen P, Pihlaja K: Inhibition of cancer cell growth by crude extract and the phenolics of Terminalia chebula retz. fruit. J Ethnopharmacol. 2002; 81: 327-36.

10. Thakur CP, Thakur B, Singh S, Sinha PK, Sinha SK: The Ayurvedic medicines Haritaki, Amala and Bahira reduce cholesterol-induced atherosclerosis in rabbits. Int $\mathrm{J}$ Cardiol. 1988; 21: 167-75.

11. Chattopadhyay RR, Bhattacharyya SK: Terminalia chebula: An update. Phcog Rev. 2007; 1: 151-6.

12. Han Q, Song J, Qiao C, Wong L, Xu H: Preparative isolation of hydrolysable tannins chebulagic acid and chebulinic acid from Terminalia chebula by high-speed counter-current chromatography. J Sep Sci. 2006; 29: 1653-7.

13. Adeloye $O A$, Akinpelu $A D$, Ogundaini $O A$, Obafemi $A C$ : Studies on antimicrobial, antioxidant and phytochemical analysis of urena lobata leave extract. J Phy. Nat. Sci. 2007; 1: $1-9$.

14. Moriyama MT, Miyazawa K, Noda K, Oka M, Tanaka M, Suzuki K: Reduction in oxalate-induced renal tubular epithelial cell injury by an extract from Quercus salicina Blume/Quercus stenophylla Makino. Urol Res. 2007; 35: 295-300.

15. Hennequin C, Lalanne V, Daudon M, Lacour B, Drueke T: A new approach to studying inhibitors of calcium oxalate crystal growth. Urol Res. 1993; 21: 101-8.

16. Nakagawa Y, Abram V, Parks JH, Lau HS, Kawooya JK, Coe FL: Urine glycoprotein crystal growth inhibitors. Evidence for a molecular abnormality in calcium oxalate nephrolithiasis. J Clin Invest. 1985; 76: 1455-62.

17. Jeong BC, Kwak C, Cho KS, Kim BS, Hong SK, Kim JI et al.: Apoptosis induced by oxalate in human renal tubular epithelial HK-2 cells. Urol Res. 2005; 33: 87-92.

18. Wagner A, Marc A, Engasser JM, Einsele A: The use of lactate dehydrogenase (LDH) release kinetics for the evaluation of death and growth of mammalian cells in perfusion reactors. Biotechnol Bioeng. 1992; 39: 320-6.

19. Atmani F, Farell G, Lieske JC: Extract from Herniaria hirsuta coats calcium oxalate monohydrate crystals and blocks their adhesion to renal epithelial cells. J Urol. 2004; 172: 1510-4. 
20. Butterweck V, Khan SR: Herbal medicines in the management of urolithiasis: alternative or complementary? Planta Med. 2009; 75: 1095-103.

21. Campos $\mathrm{AH}$, Schor N: Phyllanthus niruri inhibits calcium oxalate endocytosis by renal tubular cells: its role in urolithiasis. Nephron. 1999; 81: 393-7.

22. Vanachayangkul P, Byer K, Khan S, Butterweck V: An aqueous extract of Ammi visnaga fruits and its constituents khellin and visnagin prevent cell damage caused by oxalate in renal epithelial cells. Phytomedicine. 2010; 17: 653-8.

23. Bijarnia RK, Kaur T, Singla SK, Tandon C: A novel calcium oxalate crystal growth inhibitory protein from the seeds of Dolichos biflorus (L.). Protein J. 2009; 28: 161-8.

24. Kaur T, Bijarnia RK, Singla SK, Tandon C: Purification and characterization of an anticalcifying protein from the seeds of Trachyspermum ammi (L.). Protein Pept Lett. 2009; 16: 173-81.

\section{EDITORIAL COMIMENT}

The authors address an interested in vitro manuscript, containing a new fact, studying a possible option of lithiasis treatment. The subject of the article is particular, exposing MDCK and NRK-52E renal epitelial renal cells to oxalate induced cell injury. The manuscript concluded that the plant extract, Terminalia chebula, has a protect action against urolithiasis, inhibiting nucleation and the growth of the $\mathrm{CaOx}$ crystals.

\section{REFERENCES}

1. Boim MA, Heilberg IP, Schor N: Phyllanthus niruri as a promising alternative treatment for nephrolithiasis. Int Braz J Urol. 2010; 36: 657-64; discussion 664.
25. Aggarwal A, Tandon S, Singla SK, Tandon C: Reduction of oxalate-induced renal tubular epithelial (NRK-52E) cell injury and inhibition of calcium oxalate crystallisation in vitro by aqueous extract of Achyranthes aspera. Int J Green Pharm. 2010; 4: 159-64.

26. Pathak P, Singh SK, Tandon C: Effect of biomolecules from human renal matrix of calcium oxalate monohydrate (CaOx) stones on in vitro calcium phosphate crystallization. Int Braz J Urol. 2010; 36: 621-8.

27. Beghalia M, Ghalem S, Allali H, Belouatek A, Marouf A: Inhibition of calcium oxalate monohydrate crystal growth using Algerian medicinal plants. J Med Plant. 2008; 2: 66-70.

28. Miyazawa K, Aihara K, Ikeda R, Moriyama MT, Suzuki K: cDNA macroarray analysis of genes in renal epithelial cells exposed to calcium oxalate crystals. Urol Res. 2009; 37: 27-33.

$$
\begin{array}{r}
\text { Correspondence address: } \\
\text { Dr. C. Tandon } \\
\text { Biotechnology and Bioinformatics } \\
\text { Jaypee University of Information Technology } \\
\text { Waknaghat, 173215, Solan, India } \\
\text { E-mail: tandonchanderdeep@yahoo.com }
\end{array}
$$

The urolithiasis clinical treatment has been extensively studied with different herbs, otherwise, others studies demonstrated a potent inhibitory effect on $\mathrm{CaOx}$ crystal adhesion and endocytosis of folk plants, as Phyllanthus niruri, from South America, Africa in vitro and vivo models $(1,2)$.

This well done paper demonstrated a nice result, but it needs to be done in animal models, human cells to provide a future clinical study to be a consistent and reproducible data.

2. Bouanani S, Henchiri C, Migianu-Griffoni E, Aouf N, Lecouvey $M$ : Pharmacological and toxicological effects of Paronychia argentea in experimental calcium oxalate nephrolithiasis in rats. J Ethnopharmacol. 2010; 129: 38-45.

Dr. Lucas Batista and Dr. Juarez Andrade Federal University of Bahia

Department of Urology Associate Professor E-mail: lucastbatista@hotmail.com 


\section{EDITORIAL COMMENT}

This is a very interesting paper which addresses a subject that is not commonly seen in the urologic literature. It has been written in a satisfactory and scientific way since the type of therapy described is more commonly found in lay press and as such does not contain strong scientific subtract.

I am sure that this study brings scientific information that could lead to further studies in this area similarly as some substances used as cancer latest generation chemotherapeutic agents which were originally found in plant species. The
Brazilian species of Phyllanthus niruri L. Popularly known as "chá de quebra pedra" (Ref. 21 in the article) is an example of many plants of our flora that could have been submitted to randomized studies to try to bring answers to the prevention and eventually treatment of stone disease. This management represents a major source of loosing work force and complications for patients without mentioning the great money expenditure with sophisticated equipments like ESWL that time has proven to be not as effective as initially proposed.

The authors must be congratulated for the style and content of this manuscript.

Dr. Salvador Vilar C. Lima Universidade Federal de Pernambuco - UFPE Av. Moraes Rego S/N - Hospital das Clínicas - Bloco A Cidade Universitária Recife, PE, 50670-901, Brazil E-mail: salvilar@salvador.net 